\title{
ANALISIS KEMAMPUAN PESERTA DIDIK SMP DI BANGKINANG MELALUI PENYELESAIAN SOAL PISA 2015
}

\author{
Zulfah \\ Universitas Pahlawan Tuanku Tambusai, Jl. Tuanku Tambusai, No. 23 Bangkinang \\ Email penulis pertama: zulfahasni670@gmail.com
}

This study aims to analyze the problem solving abilities and reasoning abilities of 14-14-15 year old junior high school students through the completion of the 2015 PISA questions which are international standard questions which PISA 2015 had never been given before. This study used a qualitative research approach. Qualitative approaches were chosen with the aim of revealing more carefully the mistakes of students in completing the PISA 2015 problem. In addition, with a qualitative approach researchers can communicate directly with respondents to find out the mathematical abilities of students through the completion of the PISA 2015. Based on data analysis conducted on 120 people students by completing the 2015 PISA questions in the category of problem solving abilities of students, most of the students were unable to answer the question. The biggest obstacle experienced is students do not know the completion steps that must be done in solving the problems given. In the category of reasoning ability, where the problem is still inductive reasoning, students are able to answer well, but for deductive reasoning students are not able to provide possible answers.

Keywords: Mathematics Ability, PISA 2015

\begin{abstract}
Abstrak
Penelitian ini bertujuan untuk menganalisis kemampuan pemecahan masalah dan kemampuan penalaran peserta didik SMP di bangkinang yang berumur 14 - 15 tahun melalui penyelesaian soal PISA 2015 yang merupakan soal bertaraf internasional yangmana sebelumnya tidak pernah diberikan soal PISA 2015. Penelitian ini menggunakan pendekatan penelitian kualitatif. Pendekatan kualitatif dipilih dengan tujuan mengungkap secara lebih cermat kesalahan peserta didik dalam menyelesaikan soal PISA 2015. Selain itu, dengan pendekatan kualitatif peneliti dapat berkomunikasi langsung dengan responden untuk mengetahui kemampuan matematis peserta didik melalui penyelesaian soal PISA 2015. Berdasarkan analisis data yang dilakukan pada 120 orang peserta didik dengan menyelesaikan soal PISA 2015 pada kategori soal kemampuan pemecahan masalah peserta didik, sebagian besar pesera didik tidak bisa menjawab soal tersebut. Kendala terbesar yang dialami adalah peserta didik tidak mengetahui langkah penyelesaian yang harus dilakukan dalam menyelesaikan permasalahan yang diberikan. Pada soal kategori kemampuan penalaran, dimana soalnya masih bersifat penalaran induktif, maka peserta didik mampu menjawab dengan baik, namun untuk penalaran deduktif peserta didik tidak mampu memberikan kemungkinan jawabannya.
\end{abstract}

Kata kunci: Kemampuan Matematis, PISA 2015

Matematika pada dasarnya tidak hanya aktivitas berhitung saja, namun juga merupakan alat Matematika pada dasarnya tidak hanya aktivitas berhitung saja, namun juga merupakan alat untuk menemukan sesuatu yang baru. Penguasaan matematika memberikan kemudahan kepada manusia yang memilikinya dengan kegunaan yang beragam. Mulai dari melakukan penghitungan terhadap benda, pengukuran luas suatu bidang, pemotongan harga barang yang memperoleh diskon, memprediksi indeks harga saham gabungan dengan memanfaatkan teori double eksponensial smooting, mengendalikan glukosa darah pada penderita diabetes melitus tipe-1 dengan menggunakan model predictive control, hingga mendiagnosa cancer melalui aplikasi metode kernel (IndoMS). Sejalan dengan hal tersebut, National Research Council menyatakan bahwa matematika adalah kunci bagi manusia untuk memperoleh peluang, salah satunya peluang di dunia kesehatan. Melalui penguasaan matematika, manusia dapat memperoleh karir yang cemerlang, dapat menunjang dalam 
pengambilan keputusan yang tepat, serta mampu bersaing dan berkompetisi di berbagai bidang yang sekarang semakin berkembang pesat.

Pada dunia pendidikan khususnya di Indonesia, matematika merupakan salah satu mata pelajaran wajib yang dipelajari mulai jenjang sekolah dasar hingga sekolah menengah. Matematika juga dipelajari pada berbagai jurusan di perguruan tinggi. Secara umum, tujuan pembelajaran matematika di sekolah yaitu membekali peserta didik dengan kemampuan berpikir logis, analisis, sistematis, kreatif, inovatif, dan kreatif, serta memiliki kemampuan bekerja sama (Lampiran Permen No. 58,2014$)$. Melalui pembelajaran matematika di sekolah peserta didik diharapkan dapat memiliki kemampuan-kemampuan matematis yang diantaranya adalah kemampuan pemecahan masalah, kemampuan penalaran, komunikasi, dan kemampuan representasi. Kompetensi atau kemampuan tersebut diperlukan agar peserta didik mampu memperoleh, mengelola, dan memanfaatkan informasi untuk hidup lebih baik pada keadaan yang selalu berubah, tidak pasti, dan kompetitif (Lampiran Permen No. 58, 2014).

Kemampuan pemecahan masalah, penalaran, komunikasi, dan representasi yang dimiliki peserta didik di sekolah menengah pertama (SMP) dapat dievaluasi melalui pemberian tes berupa soal PISA 2015. Soal PISA 2015, merupakan soal yang dibuat oleh Organisation For Economic CoOperation and Development (OECD ). Program for International Student Assessment (PISA) adalah studi tentang program penilaian siswa tingkat internasional yang diselenggarakan oleh Organisation for Economic Co-Operation and Development (OECD) yang berkedudukan di Paris, Prancis. Keterlibatan Indonesia dalam PISA merupakan upaya untuk melihat sejauh mana program pendidikan berkembang dibanding dengan negara-negara lain di dunia. Hal ini menjadi sangat penting untuk melihat sejauh mana kemampuan anak-anak Indonesia dimasa akan datang mampu bersaing dengan anak-anak dari negara lain pada era globalisasi. PISA yang merupakan salah satu jenis tes yang diselenggarakan secara internasional bisa dijadikan sebagai patokan untuk menentukan sejauh mana peserta didik Indonesia mampu bersaing di era globalisasi Tujuan PISA dalam bidang matematika adalah mengukur tingkat kemampuan siswa dalam menggunakan pengetahuan dan keterampilan matematika dalam menangani masalah kehidupan sehari-hari. PISA akan memberikan informasi mengenai profil pengetahuan dan kemampuan dalam literasi matematika untuk setiap peserta didik masing-masing negara peserta. Informasi tersebut dapat dijadikan masukan dalam penentuan kebijakan dalam upaya peningkatan kualitas pendidikan disetiap negara peserta. Selain itu studi PISA digunakan untuk merumuskan kebijakan yang mendukung terciptanya sumber daya manusia yang kompetitif terhadap era globalisasi.

Studi PISA dilaksanakan dibeberapa kota di Indonesia yang dijadikan sebagai sampel dalam melakukan evaluasi melalui PISA. Bangkinang sebagai salah satu daerah di Indonesia belum pernah sama sekali melakukan evaluasi menggunakan soal PISA 2015. Agar diketahuinya bagaimana kemampuan peserta didik di Bangkinang dalam mengahadapi tantangan pada era globalisasi yang akan 
selalu berkembang, peneliti tertarik untuk menganalisis kemampuan peserta didik dalam menyelesaikan soal PISA 2015. Kemampuan yang akan dianalisis yaitu kemampuan penalaran serta kemampuan pemecahan masalah. Hal ini dikarenakan kemampuan tersebut digunakan dalam menyelesaikan soal PISA. Selain itu melalui analisis kemampuan peserta didik dalam menyelesaikan soal PISA, maka diharapkan peserta didik terlatih dan terbiasa mengerjakan soal PISA ataupun soal bertipe PISA. Berdasarkan uraian tersebut maka peneliti akan melakukan penelitian dengan judul "Analisis Kemampuan Peserta Didik SMP di Bangkinang dalam Menyelesaikan Soal PISA 2015”.

Penalaran adalah kemampuan utama lain yang ingin dikembangkan melalui pembelajaran matematika. Struktur matematika yang terdiri dari definisi-definisi, aksioma-aksioma, serta teoremateorema, serta sifat deduktif yang ketat dari matematika, membutuhkan kemampuan penalaran yang baik untuk memahaminya (Fauzan, 2011). Kemampuan penalaran dalam matematika adalah suatu kemampuan menggunakan aturan-aturan, sifat-sifat atau logika matematika untuk mendapatkan suatu kesimpulan yang benar. Penalaran tidak terlepas dari realitas, sebab yang difikirkan adalah realitas, yaitu hukum realitas yang sejalan dengan aturan berfikir dan dengan dasar realitas yang jelas serta menggunakan hukum-hukum berfikir. Rubrik skala penilaian tingkat kemampuan penalaran peserta didik dapat dilihat pada Tabel 1.

\section{Tabel 1.}

\section{Rubrik Skala Penilaian Tingkat Kemampuan Penalaran}

\begin{tabular}{|c|c|c|}
\hline $\begin{array}{c}\text { Indikator Penalaran } \\
\text { matematis }\end{array}$ & Jawaban & Skor \\
\hline \multirow{5}{*}{$\begin{array}{l}\text { Penalaran induktif: } \\
\text { Analogi matematik } \\
\text { (menarik kesimpulan } \\
\text { berdasarkan } \\
\text { keserupaan proses/ } \\
\text { konsep matematik } \\
\text { yang terlibat) }\end{array}$} & Tidak ada jawaban & 0 \\
\hline & $\begin{array}{l}\text { Mengidentifikasi kaitan antara proses/konsep pada kasus yang } \\
\text { diberikan dan menentukan nama proses/konsep yang bersangkutan }\end{array}$ & $0-3$ \\
\hline & $\begin{array}{l}\text { Mengidentifikasi kaitan antara proses/konsep pada kasus yang } \\
\text { ditanyakan }\end{array}$ & $0-2$ \\
\hline & $\begin{array}{l}\text { Memilih/menetapkan kaitan antara proses/konsep yang serupa } \\
\text { pada kedua kasus disertai dengan alasan dan nama konsep yang } \\
\text { bersangkutan }\end{array}$ & $0-3$ \\
\hline & Sub-total (satu butir tes) & $0-8$ \\
\hline $\begin{array}{l}\text { Indikator Penalaran } \\
\text { matematik }\end{array}$ & Jawaban & Skor \\
\hline \multirow{6}{*}{$\begin{array}{l}\text { Penalaran induktif: } \\
\text { Generalisasi (menarik } \\
\text { kesimpulan umum } \\
\text { berdasarkan proses/ } \\
\text { konsep matematik } \\
\text { yang terlibat }\end{array}$} & Tidak ada jawaban & 0 \\
\hline & $\begin{array}{l}\text { Mengidentifikasi proses/konsep yang terlibat pada kasus yang } \\
\text { diberikan dan menentukan namanya }\end{array}$ & $0-3$ \\
\hline & $\begin{array}{l}\text { Mengidentifikasi kaitan antar rumus/aturan/konsep matema- } \\
\text { tika yang termuat pada kasus yang bersangkutan }\end{array}$ & $0-2$ \\
\hline & $\begin{array}{l}\text { Menyusun pola berdasarkan kaitan antar rumus/aturan/ } \\
\text { konsep matematika yang telah diperoleh }\end{array}$ & $0-2$ \\
\hline & $\begin{array}{l}\text { Menyusun bentuk umum proses/konsep yang bersangkutan } \\
\text { disertai alasan/penjelasan }\end{array}$ & $0-3$ \\
\hline & Sub-total (satu butir tes) & $0-10$ \\
\hline \multirow{2}{*}{$\begin{array}{l}\text { Penalaran induktif: } \\
\text { Membuat perkiraan }\end{array}$} & Tidak ada jawaban & 0 \\
\hline & $\begin{array}{l}\text { Mengidentifikasi proses/konsep matematika dan } \\
\text { kecenderungannya dari situasi yang diberikan }\end{array}$ & $0-2$ \\
\hline
\end{tabular}




\begin{tabular}{|l|l|l|}
\cline { 2 - 3 } & Mengidentifikasi proses/konsep matematika yang ditanyakan & $0-2$ \\
\cline { 2 - 3 } & Menyusun perkiraan relevan dengan pertanyaan & $0-2$ \\
\cline { 2 - 3 } & Sub-total (satu butir tes) & $0-6$ \\
\hline $\begin{array}{l}\text { Penalaran deduktif: } \\
\text { Melaksanakan } \\
\text { perhitungan } \\
\text { berdasarkan } \\
\text { rumus/aturan } \\
\text { matematika yang } \\
\text { berlaku }\end{array}$ & Tidak ada jawaban & $\begin{array}{l}\text { Mengidentifikasi proses/konsep matematika pada situasi/ } \\
\text { masalah yang diberikan, ditanyakan, serta memeriksa } \\
\text { ketercukupan unsur }\end{array}$ \\
\cline { 2 - 3 } & Menyusun model matematika masalah & $0-3$ \\
\cline { 2 - 3 } & $\begin{array}{l}\text { Mengidentifikasi langkah-langkah perhitungan disertai } \\
\text { penjelasan proses/konsep/aturan matematika yang digunakan }\end{array}$ & $0-3$ \\
\cline { 2 - 3 } & $\begin{array}{l}\text { Menyelesaikan model matematika masalah disertai alasan atau } \\
\text { menyertakan proses/konsep/aturan matematika yang digunakan }\end{array}$ & $0-2$ \\
\cline { 2 - 3 } & Menetapkan solusi yang relevan & $0-3$ \\
\cline { 2 - 3 } & Memeriksa kebenaran solusi masalah utama & $0-2$ \\
\cline { 2 - 3 } & Sub-total (satu butir tes) & $0-15$ \\
\hline
\end{tabular}

Pemecahan masalah didefinisikan sebagai usaha mencari jalan keluar dari suatu kesulitan, mencapai suatu tujuan yang tidak dengan segera dapat dicapai. Karena pemecahan masalah merupakan suatu tingkat aktivitas intelektual yang tinggi. Tujuan pembelajaran dalam kurikulum 2013 (Permendiknas no 58, 2014) menyatakan bahwa indikator-indikator pencapaian kemampuan pemecahan masalah, meliputi.

2. 1 Memahami masalah

2. 2 Mengorganisasi data dan memilih informasi yang relevan dalam mengidentifikasi masalah

2. 3 Menyajikan suatu rumusan masalah secara matematis dalam berbagai bentuk

2. 4 Memilih pendekatan dan strategi yang tepat untuk memecahkan masalah

2.5 Menggunakan atau mengembangkan strategi pemecahan masalah

2. 6 Menafsirkan hasil jawaban yang diperoleh untuk memecahkan masalah

2. 7 Menyelesaikan masalah

Dari beberapa indikator yang ditetapkan indikator kemampuan pemecahan masalah yang digunakan dalam penelitian ini yaitu.

2. 1 Memahami masalah

2. 2 Merencanakan strategi penyelesaian dari permasalahan.

2. 3 Melaksanakan rencana penyelesaian dari permasalahan.

2. 4 Memeriksa kembali serta menarik kesimpulan.

Rubrik penilaian kemampuan pemecahan masalah dapat dilihat pada Tabel 2. Rubrik Penskoran Kemampuan Pemecahan Masalah. 


\section{Tabel 2.}

Rubrik Penskoran Kemampuan Pemecahan Masalah

\begin{tabular}{|c|c|c|c|c|}
\hline Skor & $\begin{array}{l}\text { Memahami dan } \\
\text { mempersentasika } \\
\text { n masalahnya }\end{array}$ & $\begin{array}{l}\text { Memilih atau } \\
\text { merencakan solusi } \\
\text { penyelesaian }\end{array}$ & $\begin{array}{l}\text { Melaksanakan } \\
\text { rencananya }\end{array}$ & $\begin{array}{l}\text { Mengevaluasi } \\
\text { hasilnya serta } \\
\text { menarik } \\
\text { kesimpulan }\end{array}$ \\
\hline 0 & $\begin{array}{l}\text { Salah } \\
\text { menginterpretasik } \\
\text { an/ tidak ada } \\
\text { jawaban }\end{array}$ & $\begin{array}{l}\text { Tidak ada } \\
\text { merencanakan solusi } \\
\text { penyelesaian }\end{array}$ & $\begin{array}{l}\text { Tidak ada } \\
\text { melaksanakan } \\
\text { rencana } \\
\text { penyelesaian sama } \\
\text { sekali }\end{array}$ & $\begin{array}{l}\text { Tidak ada } \\
\text { keterangan }\end{array}$ \\
\hline 1 & $\begin{array}{l}\text { Interpretasi soal } \\
\text { kurang tepat/ } \\
\text { salah } \\
\text { menginterpretasik } \\
\text { an sebagian soal }\end{array}$ & $\begin{array}{l}\text { Merencanakan solusi } \\
\text { penyelesaian yang } \\
\text { tidak relevan }\end{array}$ & $\begin{array}{l}\text { Melaksanakan } \\
\text { prosedur } \\
\text { penyelesaian yang } \\
\text { benar tetapi } \\
\text { peyelesaian kurang } \\
\text { lengkap }\end{array}$ & $\begin{array}{l}\text { Memberikan } \\
\text { kesimpulan yang } \\
\text { belum lengkap }\end{array}$ \\
\hline 2 & $\begin{array}{l}\text { Memahami soal } \\
\text { dengan baik }\end{array}$ & $\begin{array}{l}\text { Merencanakan solusi } \\
\text { penyelesaian yang } \\
\text { kurang relevan } \\
\text { sehingga tidak dapat } \\
\text { dilaksanakan dengan } \\
\text { sempurna }\end{array}$ & $\begin{array}{l}\text { Melaksanakan } \\
\text { prosedur dan } \\
\text { penyelesaian yang } \\
\text { benar }\end{array}$ & $\begin{array}{l}\text { Memberikan } \\
\text { kesimpulan yang } \\
\text { benar dan lengkap }\end{array}$ \\
\hline 3 & - & $\begin{array}{l}\text { Membuat rencana } \\
\text { penyelesaian yang } \\
\text { baik, namun belum } \\
\text { lengkap }\end{array}$ & - & - \\
\hline 4 & - & $\begin{array}{l}\text { Membuat rencana } \\
\text { penyelesaian yang } \\
\text { benar dan lengkap }\end{array}$ & - & - \\
\hline
\end{tabular}

PISA merupkan studi bertaraf internasional yang diselenggarakan $O E C D$ yang berkedudukan di Paris, Prancis. PISA mengkaji kemampuan literasi peserta didik pada rentang usia 15-16 tahun dan diikuti oleh 72 negara termasuk Indonesia. PISA dilaksanakan sekali dalam tiga tahun. Penilaian pertama dilakukan pada tahun 2000 dan terakhir dilaksanakan pada tahun 2015.

PISA bertujuan untuk menilai sejauh mana peserta didik yang berusia 15 tahun usia dimana peserta didik di sebagian besar negara mendekati akhir dari wajib belajar. Hal-hal yang dinilai dalam studi PISA meliputi literasi matematika, literasi membaca, dan literasi sains. Survei PISA yang dilaksanakan sekali dalam tiga tahun ini bertujuan untuk membandingkan kinerja peserta didik dari waktu ke waktu dan menilai dampak dari keputusan kebijakan pendidikan. Puspendik Balitbang Kemendikbud (2012) juga menjelaskan bahwa studi PISA berfungsi sebagai evaluasi administratif dimana hasilnya akan menunjukkan sejauh mana pencapaian pendidikan di suatu negara dibandingkan dengan negara peserta lainnya. Dengan demikian, dari hasil studi PISA diperoleh pemetaan dari negaranegara peserta studi PISA mengena pencapaian pendidikan serta kekuranngan untuk setiap negara peserta. 


\section{METODE}

Penelitian ini menggunakan pendekatan penelitian kualitatif. Penelitian kualitatif adalah penelitian yang dimaksudkan untuk memahami fenomena tentang apa yang dialami subjek penelitian misalnya perilaku, persepsi, motivasi, tindakan dan sebagainya secara holistik dan dengan cara deskripsi dalam bentuk kata-kata dan bahasa, pada suatu konteks khusus yang alamiah dan dengan memanfaatkan berbagai metode ilmiah (Moleong, 2011). Penelitian kualitatif adalah penelitian yang digunakan untuk menggambarkan, menjelaskan dan menjawab persoalan-persoalan tentang fenomena dan peristiwa yang terjadi pada saat ini (Arifin, 2011: 41). Pendekatan kualitatif dipilih dengan tujuan mengungkap secara lebih cermat kemampuan peserta didik dalam menyelesaikan soal PISA 2015. Selain itu, dengan pendekatan kualitatif peneliti dapat berkomunikasi langsung dengan responden untuk mengetahui kemampuan peserta didik dalam menyelesaikan soal PISA 2015.

Teknik pengumpulan data yang digunakan dalam penelitian ini yaitu dengan menggunakan observasi, tes, dan wawancara. Tahap analisis data dalam penelitian ini yaitu reduksi data, penyajian data, dan verifikasi data atau penarikan kesimpulan. Penelitian dilaksanakan di SMP Negeri 1 Bangkinang Kota, dan SMP Negeri 2 Bangkinang Kota.

\section{HASIL DAN PEMBAHASAN}

\section{Kemampuan Penalaran Matematis}

\section{Analisis Soal No 1}

Berdasarkan hasil analisis lembar jawaban 120 orang peserta didik diperoleh data bahwa hanya 6 orang peserta didik yang salah dalam memperkiraan bentuk tumpukan barang jika dilihat dari atas, dan 4 orang tidak memberikan jawabannya. 110 orang peserta didik sudah dapat mengidentifikasi proses matematika yang diberikan, menyusun perkiraan yang relevan dengan pertanyaan, memperoleh jawaban yang tepat, dan memperoleh skor tinggi.

\section{Analisis Soal No 6}

Pada soal nomor 3, peserta didik diarahkan untuk menggunakan penalaran induktif engan menarik kesimpulan umum berdasarkan proses atau konsep matematika yang terlibat (generalisasi). Melalui analisis jawaban peserta didik, 90 orang peserta didik mampu memberikn penalaran yang baik. Pernyataan ini dikuatkan dengan pelaksanaan wawancara kepada peserta didik. Peserta didik menyatakan bahwa perbandingan dilihat melalui panjang garis kanan dan kiri hampir sama, tidak ada yang tidak sama panjang sisi kanan dan kirinya. Sehingga 90 orang peserta didik mendapat skor tinggi, sedangkan 40 orang peserta didik memilih untuk tidak menjawab pertanyaan tersebut.

\section{Analisis Soal No 7}

Soal nomor 13 termasuk kedalam soal penalaran induktif yang mengarahkan peserta didik membuat perkiraan. Dari 120 orang peserta didik hanya 9 orang peserta didik yang dapat memperkirakan dengan tepat dan mendapat skor tinggi, 16 orang peserta didik yang hampir tepat, 
peserta didik tersebut menggunakan batu bata nomor dua terkecil dari batu yang ada pada gambar, sehingga mendapat skor sedang. Sedangkan 105 orang peserta didik tidak memberikan jawaban yang tepat, ada juga peserta didik yang kebingungan dengan pertanyaan dan tidak menjawabnya.

\section{Analisis Soal No 17}

Pada soal nomor 17 peserta didik juga diarahkan untuk membuat dugaan dari pertanyaan yang diberikan. Peserta didik diminta untuk memperkirakan kemungkinan sisi sekeping uang logam yang dilemparkan dan disajikan dengen data beberapa kali percobaan. Karena data yang diberikan dari sebanyak empat kali percobaan, hasilnya empat kali muncul angka. 39 peserta didik menyatakan kemungkinan muncul bisa angka atau gambar. 77 orang peserta didik menjawab angka. Sedangkan empat orang peserta didik tidak menjawab. Sehingga hanya 39 orang peserta didik yang mendapat skor tinggi.

\section{Analisis Soal No 33}

Soal nomor 33 peserta didik diarahkan untuk bernalar secara deduktif dengan melaksanakan perhitungan berdasarkan rumus atau aturan matematika yang berlaku. Berdasarkan analisis lembar jawaban peserta didik pada soal nomor 33 yang menggunakan penalaran deduktif, 21 peserta didik mampu mengidentifikasi konsep matematika pada situasi yang diberikan, peserta didik tersebut juga mampu menyusun persamaan matematika yaitu pengangguran merupakan usia kerja dikurang pekerja. Peserta didik tersebut juga mampu menyelesaikan model matematika dan memperoleh jawaban yang tepat.

\section{Analisis Soal No 34}

Soal nomor 34 memiliki kaitan dengan nomor 33. Pada soal nomor 34, hanya 18 orang peserta didik yang mampu menjawab dengan tepat yaitu 110 orang yang termasuk usia kerja. Selebihnya tidak memberikan jawaban yang tepat. Pada lembar jawaban peserta didik ada yang beranggapan bahwa jumlah angkatan kerja adalah jumlah usia kerja ditambah jumlah pekerja di kota C. Sehingga diperoleh jawaban yang tidak tepat.

\section{Analisis Soal No 36}

Soal nomor 35 merupakan soal dengan penalaran induktif dengan menganalogi matematika, artinya menarik kesimpulan berdasarkan keserupaan proses atau konsep matetmatika yang terlibat. Terdapat beberapa macam cara penyajian jawaban oleh peserta didik. Ada yang membuat gambar sendiri dan simbol sendiri dan menentukan jumlah lampu taman, kursi taman, dan pohon palm yang diperlukan. Ada juga peserta didik yang sudah dapat memperkirakan lampu taman dan pohon palm, namun menggunakan pola bilangan untuk menentukan jumlah kursi taman dengan ukuran $10 \mathrm{~m}$ x 10 $\mathrm{m}$. Dari 120 orang 47 orang peserta didik dapat membuat jawaban yang tepat, dan mendapat skor tinggi. 20 orang menjawab dengan skor sedang, dan selebihnya tidak memberikan jawaban. 


\section{Kemampuan Pemecahan Masalah Matematis}

Kemampuan pemecahan masalah matematis peserta didik dilihat melalui penyelesaian soal PISA 2015. Soal PISA 2015 yang dikategorikan sebagai soal pemecahan masalah adalah soal nomor $10,11,16,19,21,23,28$, dan 32. Soal-soal tersebut dikategorikan sebagai soal pemecahan masalah melalui tahap validitas oleh pakar, dan diskusi teman sejawat.

\section{Analisis Soal No. 10}

Berdasarkan analisis soal nomor 10, diperoleh data bahwa rata-rata peserta didik menggunakan teori barisan yang sudah dipelajari sebelumnya. Cuplikan jawaban peserta didik sebagai berikut

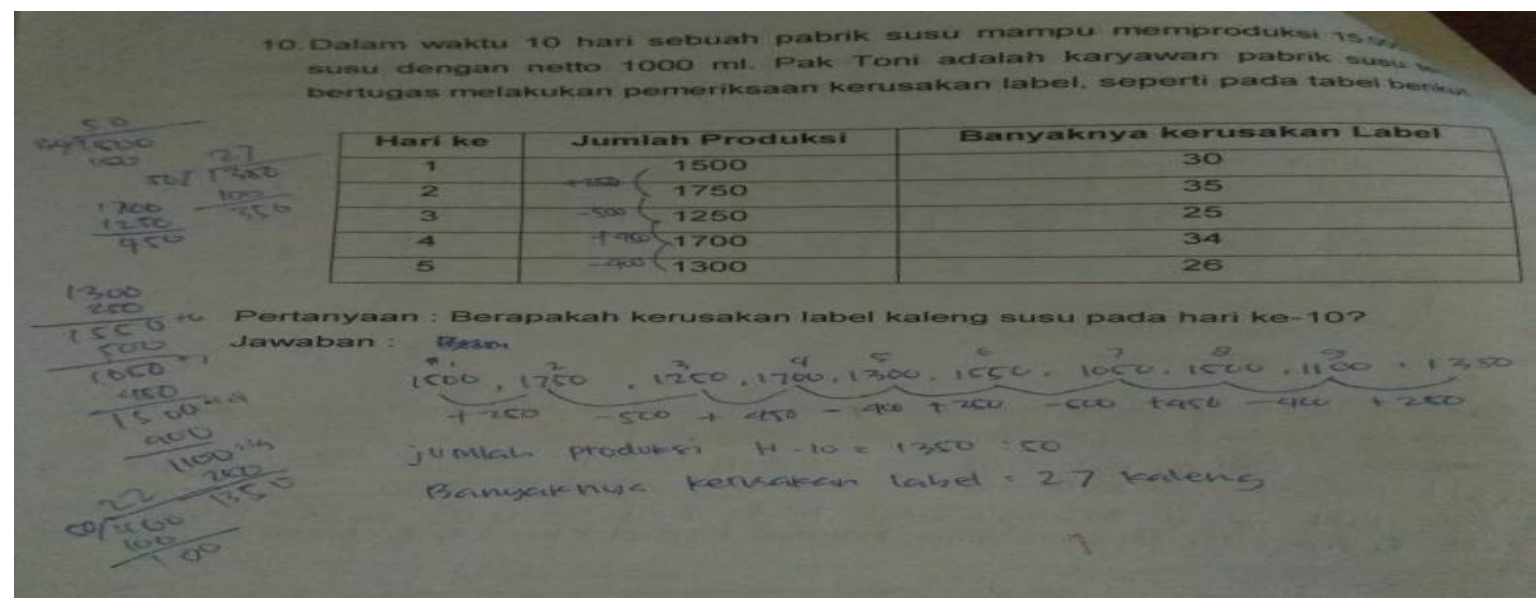

Gambar 1. Cuplikan Jawaban Nomor 10

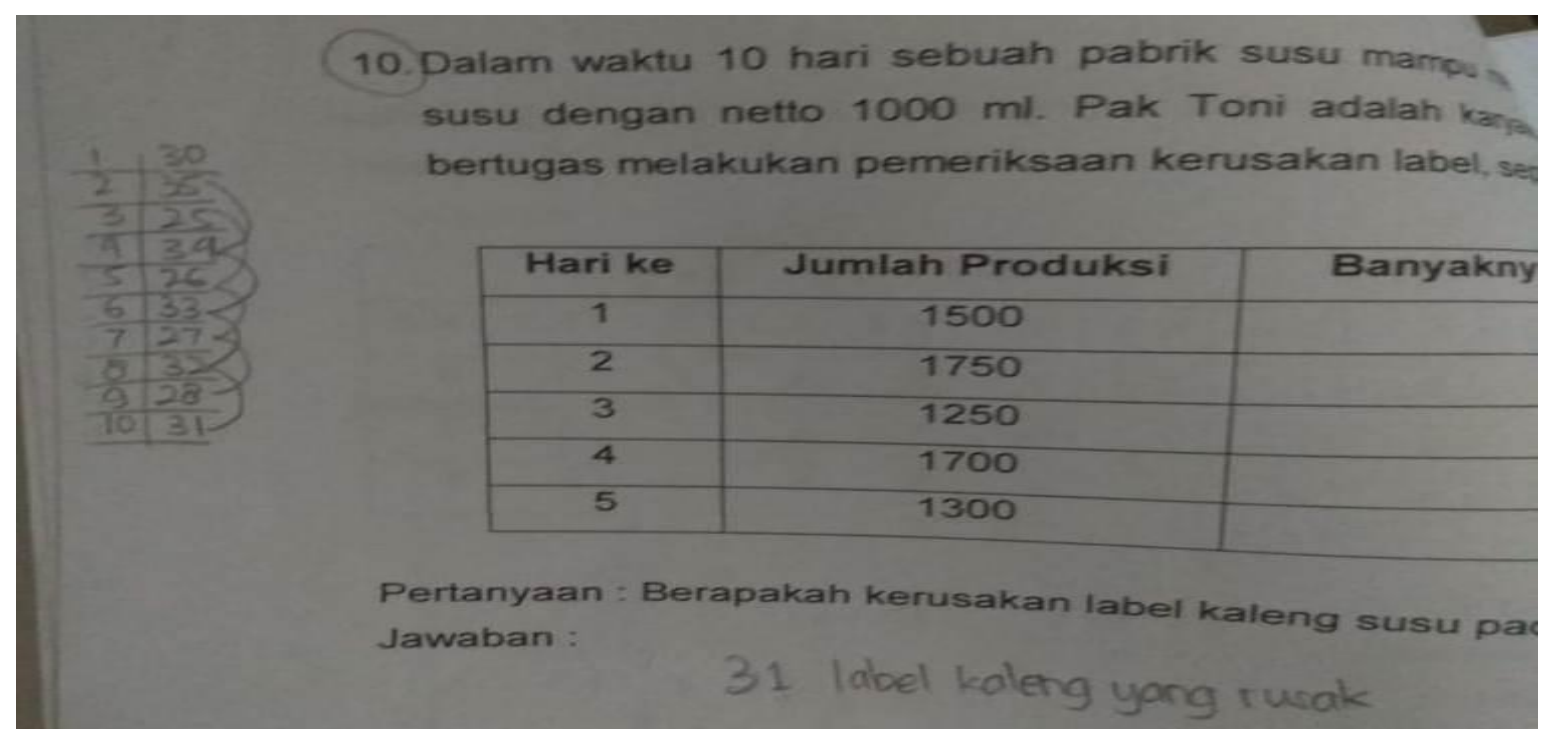

Gambar 2. Cuplikan Jawaban Nomor 10

Pada Gambar 1 dan 2, terlihat siswa mencari pola dari barisan yang dimilikinya. Pola yang dibuat juga berbeda-beda antar peserta didik. Dari 120 orang peserta didik, 67 orang peserta didik menunjukkan kemampuan pemecahan masalahnya dengan baik dan menjawab dengan tepat permasalahan yang diberikan, 29 orang peserta didik menjawab dengan nilai sedang, dan 24 orang peserta didik tidak 
menjawab permasalahan yang diberikan. Pada soal ini, diperoleh data bahwa peserta didik dengan nilai rendah mengalami masalah pada indikator merencanakan penyelesaian dan pelaksanaan penyelesaian.

\section{Analisis Soal No. 11}

Berdasarkan analisis soal nomor 11 diperoleh data bahwa peserta didik belum memahami permasalahan dengan baik. Sebagian besar peserta didik hanya menerka-nerka jawaban dari soal yang diberikan. Ada juga peserta didik yang menggunakan sifat segitiga sama kaki, namun tidak memeriksa kebenaran data yang diperolehnya. Ada juga peserta didik yang melakukan eksperimen untuk menentukan sisi ketiga dari segitiga tersebut. 10 dari 120 peserta didik menjawab dengan baik permasalahan yang diberikan, 9 orang peserta didik membuat jawaban mengenai sisi ketiga dari segitiga dengan menggunakan sifat segitiga sama kaki, karena diketahui ada sisi dengan panjang 15 dan sisi dengan panjang 36, maka sisi ketiga yang ditulis peserta didik adalah 15 atau 36. Cuplikan jawaban peserta didik dapat dilihat pada Gambar berikut.

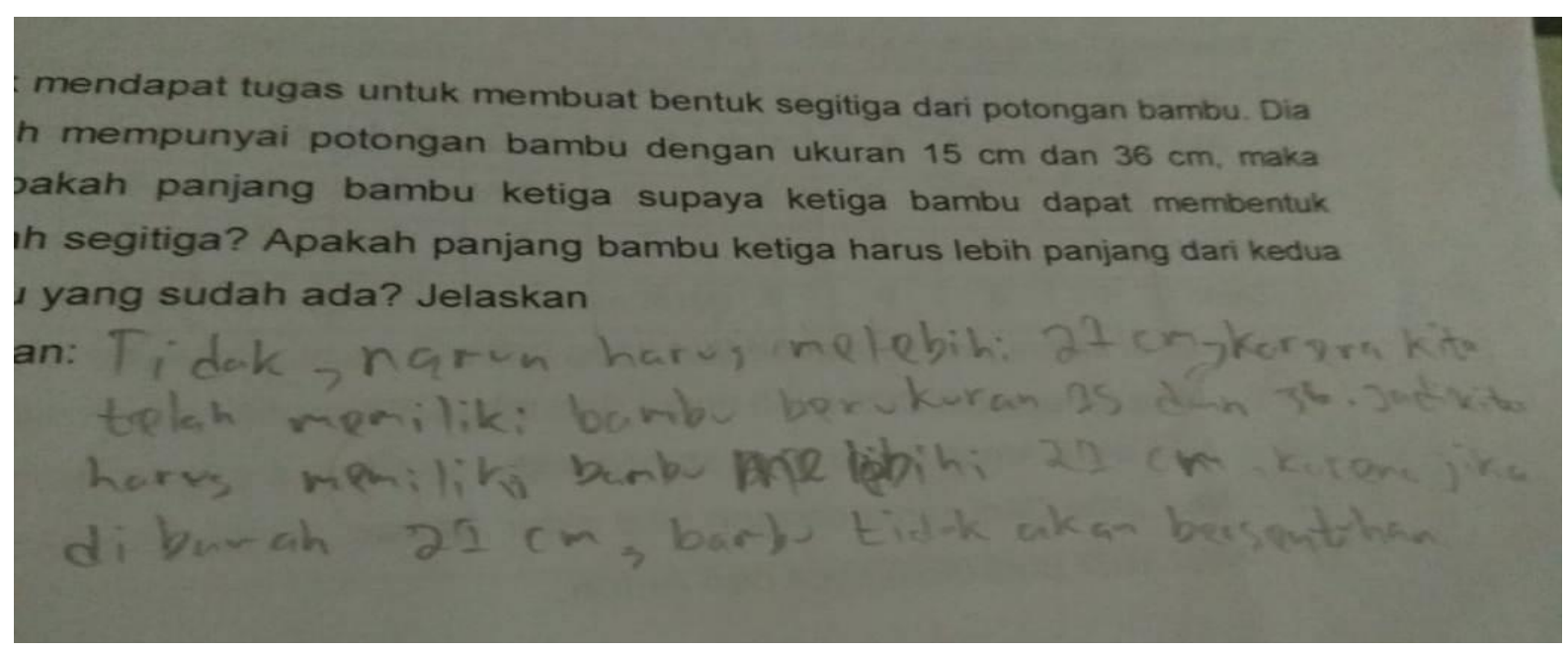

Gambar 3. Cuplikan Jawaban Nomor 10

Analisis Soal No. 16

Soal nomor 16 selain dikategorikan sebagai soal representasi matematis juga peneliti kategorikan sebagai soal pemecahan masalah. Melalui soal ini dapat dilihat pemahaman dan kemampuan interpretasi pesertadidik terhadap permasalahan, kemampuan merencanakan dan melaksanakan penyelesaian terhadap permasalahan, dan mengambil kesimpulan. Pada lembar jawaban peserta didik, ada peserta didik yang memang sudah memahami permasalahan dan ada juga yang salah dalam memahami permalahan yang diberikan. 


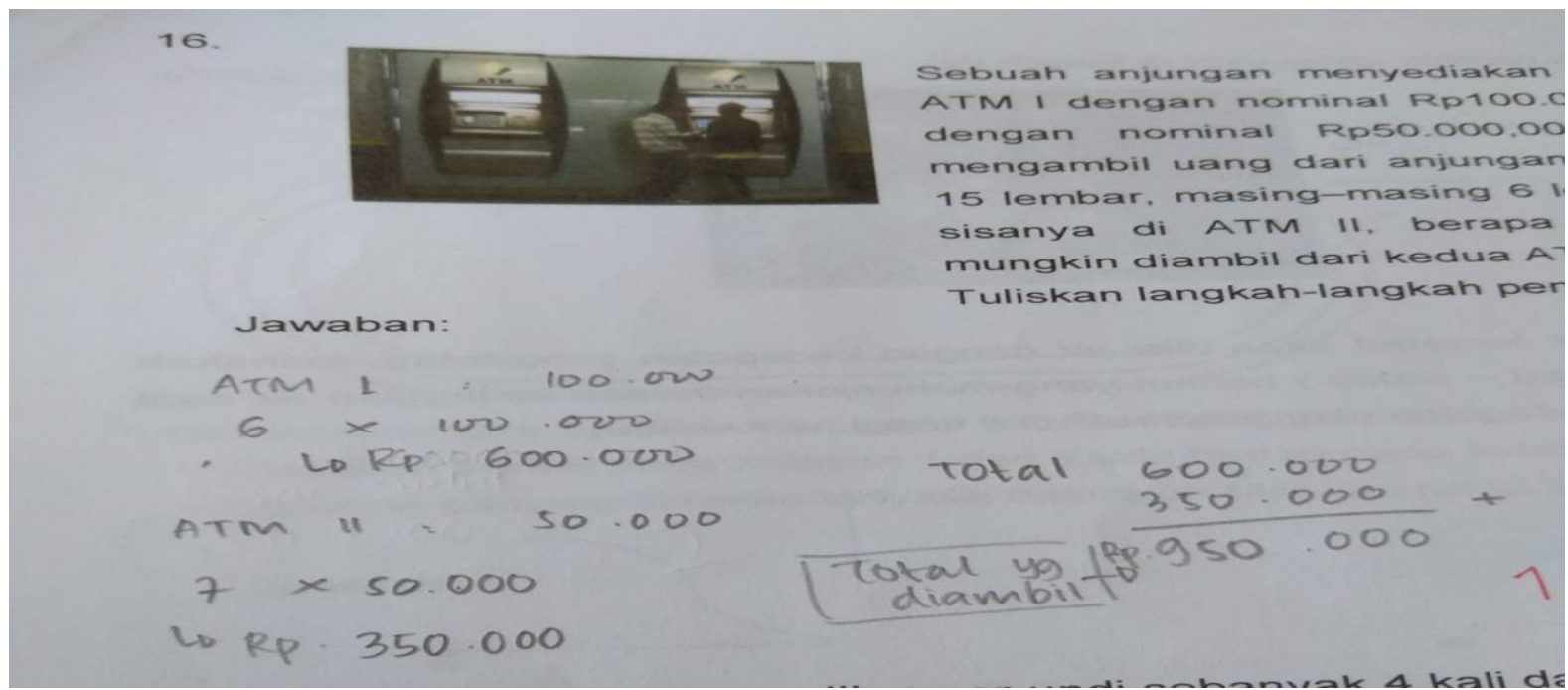

Gambar 4. Cuplikan Jawaban Nomor 16

\section{Analisis Soal No. 19}

Berdasarkan analisis soal nomor 19 diperoleh informasi bahwa terdapat berbagai macam cara peserta didik dalam menjawab permasalahan. Ada peserta didik yang merencanakan dan melaksanakan sebagian dari langkah penyelesaian yang seharusnya. Terdapat peserta didik yang menghitung panjang lintasan tanpa menghitung panjang sisi kanan dan kiri lapangan yang merupakan setengah lingkaran. Ada juga peserta didik yang hanya menggunakan diameter dari lingkaran. Cuplikan lembar jawaban peserta didik untuk soal nomor 19 sebagai berikut.

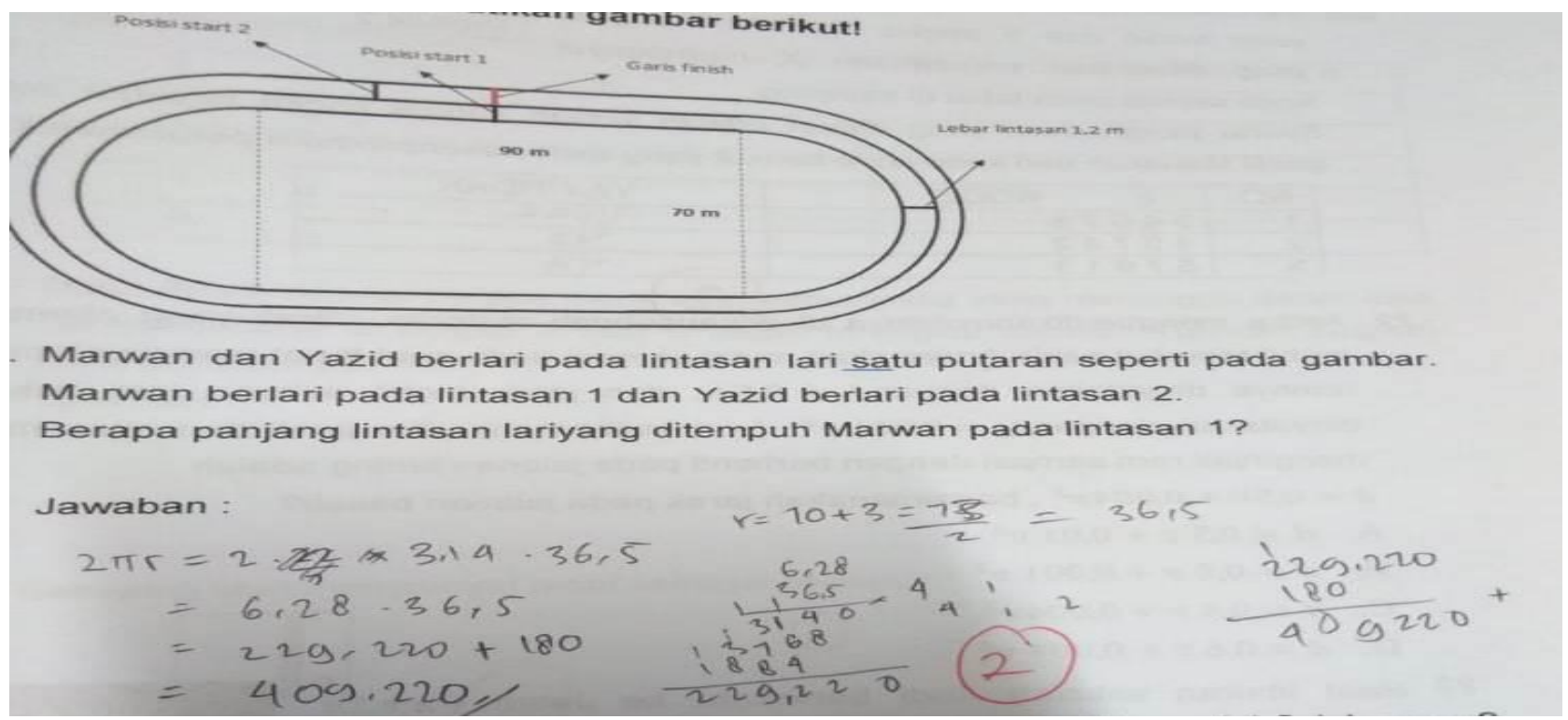

Gambar 5. Cuplikan Jawaban Nomor 19

Gambar 5 adalah lembar jawaban peserta didik yang menjawab dengan baik soal yang diberikan. Kendala yang terjadi hanyalah peserta didik kurang teliti dengan jari-jari dari lintasan yang berbentuk lingkaran. Dari 120 orang peserta didik, 40 orang peserta didik menjawab dengan sangat baik dan memperoleh nilai tinggi, 27 orang peserta didik menjawab dengan nilai sedang, dan 53 orang peserta 
didik mendapat nilai rendah. Rata-rata dari 53 orang peserta didik memberikan penyelesaian yang tidak relevan terhadap soal yang diberikan.

\section{Analisis Soal No.21}

Pada soal nomor 21, sebagian besar peserta didik mampu menjawab soal dengan baik. Peserta didik sudah memahami soal dengan baik, dan mencari penyelesaian yang tepat. 108 orang peserta didik mampu memecahkan masalah dengan baik, dan 12 orang peserta didik melaksanakan sebagian penyelesaian dengan baik dan memperoleh nilai sedang.

\section{Analisis Soal No.23}

Soal nomor 23 peneliti kategorikan sebagai soal pemecahan masalah. Pada nomor ini hanya 33 orang peserta didik yang mampu memecahkan permasalahan berdasarkan data yang diberikan. Selebihnya tidak mampu menemukan dan tidak mencari jawabannya.

\section{Analisis Soal No.28}

Berdasarkan analisis soal nomor 28 diperoleh informasi bahwa sebagai besar peserta didik sudah mampu menyelesaikan permasalahan yang diberikan. Dari 120 orang peserta didik, 89 orang mampu menemukan solusi dari permasalahan mengenai tarif seluler yang murah.

\section{KESIMPULAN}

Berdasarkan hasil penelitian yang telah dilakukan dapat disimpulkan sebagai berikut.

1. Berdasarkan analisis data yang dilakukan pada 120 orang peserta didik dengan menyelesaikan soal PISA 2015 pada kategori soal komunikasi matematis, peserta didik masih lemah dalam membuat model matematika, menggunakan strategi yang sesuai sehingga dapat memenuhi kebutuhan pemecahan masalah. Pada bagian komputasi atau perhitungan sebagian besar peserta didik sudah memiliki kemampuan yang baik. Selanjutnya diikuti dengan rendahnya kemampuan merefleksikan grafik ke dalam ide-ide matematika

2. Kemampuan representasi matematis merupakan salah satu tujuan dari pembelajaran matematika di sekolah. Kemampuan ini erat kaitanyanya dengan kemampuan komunikasi dan pemecahan masalah. Untuk dapat mengkomunikasikan sesuatu, sesorang perlu representasi baik berupa gambar, grafik, diagram, maupun bentuk representasi lainnya (Sabirin, 33: 2014).

3. Kemampuan representasi visual dari penyajian tabel, peserta didik sudah mampu menyajikan kembali data atau informasi dari suatu tabel menjadi bentuk lain seperti pola barisan. Karena peserta didik sudah mempelajari materi barisan dan deret. Pada representasi ini terdapat bermacam bentuk atau pola yang diberikan sehingga menunjukkan kemampuan representasi visual yang baik

4. Kemampuan representasi visual gambar dimana peserta didik membuat gambar bagian-bagian geometri untuk menyelesaikan permasalahan dan memfasilitasi penyelesaian masalah. Berdasarkan lembar jawaban peserta didik, peserta didik sudah mampu membuat gambar geomertri dengan baik. Membuat gambar segitiga dengan tepat. Kendalanya hanya pada pemakaian sifat-sifat dari segitiga tersebut. 
5. Kemampuan representasi simbolik atau persamaan atau ekspresi matematika yang dimiliki peserta didik sudah dimiliki hampir sebagian peserta didik. Dari 120 orang peserta didik 50 orang sudah mampu membuat model matematika dengan tepat. Model matematika dalam hal ini berupa rumus luas persegi. Peserta didik sudah mampu melaksanakan penyelesaian masalah dengan menggunakan rumus luas persegi tersebut yang dikategorikan ke dalam model matematika atau ekspresi matematika. Sedangkan 70 orang peserta didik lainnya, tidak bisa mengubah permasalahan yang diberikan menjadi persamaan atau model matematika yang diinginkan.

6. Berdasarkan analisis lembar jawaban pada soal yang dikategorikan representasi verbal diperoleh kemampuan verbal (kata-kata atau teks tertulis) yang dimiliki sebagai besar peserta didik sudah baik. Peserta didik tersebut sudah mampu menuliskan langkah-langkah penyelesaian dengan baik dan teratur.

Berdasarkan analisis lembar jawaban peserta didik, diketahui pada soal yang juga dikategorikan soal pemecahan masalah peserta didik mengalami kesulitan dalam membuat situasi masalah berdasarkan data atau representasi yang diberikan serta membuat persamaan atau model matematis dari representasi yang diberikan

\section{DAFTAR PUSTAKA}

Aminah, S., Wijaya, T. T., \& Yuspriyati, D. 2018. Analisis Kemampuan Komunikasi Matematis Siswa Kelas Viii Pada Materi Himpunan, 1(1), 15-22.

Ahmad Fauzan. 2011. Evaluasi Pembelajaran Matematika: Pemecahan Masalah Matematika. Padang: UNP.

Ali Mahmudi,. 2009. Komunikasi Dalam Pembelajaran Matematika. Jurnal MIPMIPA UNHALU Volume 8, Nomor 1, 2009.

Arifin, Z. 2011. Penelitian Pendidikan. Bandung: PT Remaja Rosdakarya.

Bungin, Burhan. 2003. Analisis Data Penelitian Kualitatif: Pemahaman Filosofis dan Metodologis ke Arah Penguasaan Model Aplikasi. Jakarta: Raja Grafindo Persada.

Bahrul Hayat - Suhendra Yusuf. 2010. Benchmark Internasional Mutu Pendidikan Jakarta: PT. Bumi Aksara.

Erna, N. D., Umi, K. A., \& Ari, I. (2017). The Math Problem Solving Profile in Solve Linear Programming' sProblem Based On Mathematic Communication Ability, 6(1), 53-59. Retrieved from http://journal.unipma.ac.id/index.php/jipm JIPM

Fauzan, A. Y. (2013). Pengaruh Pendekatan RME dan Kemandirian Belajar Terhadap Kemamampuan Matematis Siswa. In Prosiding Semirata FMIPA Universitas Lampung (pp. 7-14).

H, Hendriana., E,E Rohaeti., U Sumarmo.(2017) Hard Skills dan Soft Skill Matematik Peserta Didik, 60. 
Hodiyanto. (2017). Kemampuan Komunikasi Matematis dalam Pembelajaran Matematika. AdMathEdu, V(7).

Mahdiansyah dan Ramhawati. 2014. Literasi Matematika Siswa Pendidikan Menengah: Analisis Menggunakan Desain Tes Internasional dengan Konteks Indonesia. Jurnal Pendidikan dan Kebudayaan, Vol. 20, Nomor 4, Desember 2014, hlm. 452- 469.

Moleong, L.J. 2011. Metodologi Penelitian Kualitatif. Jakarta: Remaja Rosdakarya.

OECD. (2016). PISA 2015 Assessment and Analytical Framework: Science, Reading, Mathematic and Financial Literacy. Paris: OECD Publishing.

OECD. 2013. PISA 2012 Assesment and Analytical Framework. OECD Publishing. Online Permendiknas No 58 tahun 2014. 2014. Jakarta.

Purwati, H., \& Nugroho, A. A. (2009). Analisis Kemampuan Komunikasi Matematis Mahasiswa Dalam Menyelesaikan Masalah Pada Mata Kuliah Program Linear. Jurnal Ilmiah Pendidikan Matematika, 1(2), 127-134.

Puspendik Balitbang Kemdikbud. 2012. Survei Internasional PISA.

Shiel, Gerry. 2007. PISA Mathematics : A Teacher's Guide. Dublin: Stationery Office.

Stacey, K. 2011. The PISA View of Mathematical Literacy in Indonesia. IndoMS. J.M.E. Vol. 2 No.2 Juli 2011. Hlm. 95 -126

Sabirin, Muhammad. (2014). Representasi Dalam Pembelajaran Matematika. JPM IAIN Antasari. Volume 01 Nomor 02Januari - Juni 2014.

Sugiyono. 2012. Metode Penelitian Kuantitatif Kualitatif dan R \& D. Bandung: Alfabeta. UNESCO. 2014. Literacy for All. Http://en.unesco.org/themes/literacy-all. Diakses 1 Mei 2017 White, A. L. 2010. Numeracy, Literacy and Newman's Error Analysis. Journal of Science and Mathematics Educatio in Southeast Asia 2010. Vol. 33 No. 2. 